\title{
Three Coagulation Related Mutations and Increased Risk of Myoma in Women of Fars Province
}

\author{
Razieh Moghtaderi Nasab, ${ }^{1}$ Mahboobeh Nasiri, ${ }^{1, *}$ and Ahmad Ebrahimi ${ }^{2}$ \\ ${ }^{1}$ Department of Biology, Arsanjan Branch, Islamic Azad University, Arsanjan, IR Iran \\ ${ }^{2}$ Cellular and Molecular Research Center, Research Institute for Endocrine Sciences, Shahid Beheshti University of Medical Sciences, Tehran, IR Iran \\ "Corresponding author: Mahboobeh Nasiri, Department of Biology, Arsanjan Branch, Islamic Azad University, Arsanjan, IR Iran. Tel: +98-9173010601, E-mail: nasiri@iaua.ac.ir
}

Received 2015 September 04; Revised 2015 October 19; Accepted 2016 September 24.

\begin{abstract}
Background: Myoma is one of the most common benign tumor in the women's genital tract and causing some implications such as miscarriages, anemia or even infertility. Since tumorigenesis is associated with a hypercoagulant state, we investigate the role of coagulation related variations in methylene-tetra hydrofolate reductase (MTHFR) and endothelial protein C receptor (EPCR) genes in patients with uterine myoma.

Methods: In this case- control study, genotyping was performed for rs867186, rs1801131 and rs1801133 by amplification-refractory mutation system- polymerase chain reaction (ARMS-PCR) method in 73 patients with myoma and 73 healthy women. Data was analyzed by logistic regression and $\chi^{2}$ test through software SPSS 16 .

Results: A statistically significant difference was observed between patients and the control group regarding the frequency of allele $\mathrm{C}$ in the MTHFR $(A 1298 C)$ gene $(\mathrm{P}=0.01)$. The frequency of the genotypes carries at least one $\mathrm{C}$ allele $(\mathrm{CC}+\mathrm{AC})$ is higher in patients (13.7\%) compared to controls (2.7\%). This means the $\mathrm{C}$ allele increases the risk of the disease $(\mathrm{P}=0.01)$. Although the frequency of the $\mathrm{T}$ allele in patients was higher than controls, no significant relationship was observed between it and the risk of the disease. Our studied population was completely homogeneous for allele A at EPCR locus.

Conclusions: In conclusion, results revealed a significant association between A1298T variation and myoma incidence, but more research is needed to verify the role of this mutation as a genetic marker in uterine myoma.
\end{abstract}

Keywords: Uterine Myoma, MTHFR, EPCR, Polymorphism

\section{Background}

Myoma is one of the most frequent tumors in the women's genital tract, especially in women of reproductive and menopause age [1]. Although the risk factors of myoma are not completely clear, some molecules such as estrogen, progesterone and the growth factors such as insulin like transforming growth factor $\beta$ (TGF $\beta$ ) [2] and fibroblast growth factor (FGF) have been found related to the myoma [3]. Since hemostasis and coagulation system are responsible for pleiotropic function in cancer progression by forming the tumor microenvironment and metastatic niches through thrombin-dependent fibrin deposition and platelet activation, these two processes are considered as a probable pathogenic candidate for myoma [4]. These also have a significant role in the initiation and growth of tumors by inhibitory antibodies [4]. Tumorigenesis is associated with a hypercoagulant state and elevates the risk of thrombosis to four times [5]. New investigations have focused on the impact of inhibition of blood clotting proteins on cancer survival [6,7]. EPCR and MTHFR are two genes with significant effects on thrombosis and some of their variations show correlation with increased formation of some tumors [8-10]. Protein C (PC) is a major component of the coagulation cascade. The interaction of PC-EPCR enhances the activation of PC about 20-fold. EPCR is a type I transmembarane receptor localized on the endothelial cells of large blood vessels. In addition to its APC (activated PC)-related functions, it plays an important role in thrombosis and inflammation too [11].

One of the most well-known variations in EPCR gene is rs867186 (AGT > GGT) which is associated with higher levels of Protein $C$ and decreases the chance of thrombosis [12]. The role of two mutations in the MTHFR gene (C677T and $\mathrm{A1298C}$ ) in thrombosis has been proven and their influence on the incidence of tumorigenesis in several kinds of tumor such as brain cancer, breast cancer, colorectal cancer, ovarian cancer, prostate cancer have been reported [1315]. The substitution of C677T nucleotide of MTHFR gene, which reduces enzyme activity and results in increasing the level of homocysteine, can also be an important risk factor for venous thrombosis [16]. Hyperhomocyteinemia 
is another risk factor for thrombosis and the formation of blood clots [17]. The other polymorphism in the MTHFR gene, A1298C, results in the replacement of glutamic acid with alalnine. The $1298 \mathrm{C}$ allele clearly reduces MTHFR activity and may contribute to hyperhomocyteinemia.

However, several studies have reported the role of thrombosis in myoma tumors, which support the development of coagulation in myoma cases; there is no published research on the role of coagulation factors in myoma based on our knowledge $[12,18]$.

\section{Objectives}

The aim of this study was to investigate the role of three variations in two coagulation factors; EPCR and MTHFR, in the incidence of uterine myoma in Fars province.

\section{Methods}

\subsection{Subjects}

This case- control study was carried out in the hematology research centre, Shiraz University of medical Sciences from August 2014 to March 2015. Blood samples were collected from 73 women with uterine myoma with average age $38.4 \pm 7$ (mean \pm SD) and 73 controls (50.5 \pm 7 ) which gathered from Hazrate Zeynab hospital, Shiraz, Iran. All patients verified by laparoscopy technique. All the clinical procedure was approved by the hospital and the participants filled consent prior to their inclusion in the study.

\subsection{Genotyping}

The genomic DNA was extracted from blood samples contain Ethylenediaminetetraacetic acid (EDTA) with proteinase K method. The quantity of the extracted DNA was evaluated by spectrophotometry nanodrop and agarose gel electrophoresis. Genotyping was done using the thermal cycler BioRad T100 machine with the amplification refractory mutation system (ARMS-PCR) method. Primers were designed by primer 3 software and then evaluated by SNP check software for the probable existence of any single nucleotide polymorphism (SNP) in their length especially at the 3' end. Primers and the length of the PCR products are listed in Table 1 . The PCR condition for A1298C was as follows: Initial denaturation at $95^{\circ} \mathrm{C}$ for 3 minutes, followed by 30 cycles of; denaturation at $94^{\circ} \mathrm{C}$ for 15 seconds, annealing at $58.5^{\circ} \mathrm{C}$ for 30 seconds and extension at $72^{\circ} \mathrm{C}$ for 30 seconds. The amplification of $\mathrm{C} 677 \mathrm{~T}$ marker done in a condition as: primary denaturation at $95^{\circ} \mathrm{C}$ for 3 minutes, denaturation at $94^{\circ} \mathrm{C}$ for 35 seconds, annealing at $59.7^{\circ} \mathrm{C}$ for 45 seconds and extension at $72^{\circ} \mathrm{C}$ for 30 seconds, so that three last steps repeated for 35 cycles. Finally, the condition related to EPCR polymorphism was; primary denaturation at $95^{\circ} \mathrm{C}$ for 3 minutes, 30 cycle repeats of denaturation at $94^{\circ} \mathrm{C}$ for 35 seconds, annealing at $65^{\circ} \mathrm{C}$ for 30 seconds and extension at $72^{\circ} \mathrm{C}$ for 30 seconds. Then one cycle of final extension step at $72^{\circ} \mathrm{C}$ for 5 minutes sets for all. Two reactions were done for each sample, each with an allelespecific primer. Totally, 5 primers were used, a pair of internal control hemoglobin subunit gamma 1(HBG1) gene, a common primer and two allele specific primers. The PCR mix was prepared as follows with slight difference for each polymorphism: $5 \mu \mathrm{L}$ of $1 \mathrm{X}$ PCR master mix, $10 \mathrm{pmoL}$ of each allele specific primers, 4.5 pmoL of common primer, 2 pmoL of each HBG1 primers, 100 ng of genomic DNA plus $\mathrm{dH}_{2} \mathrm{O}$ up to the final volume of $15 \mu \mathrm{L}$. The products were then resolved on $2 \%$ agarose gel electrophoresis and stain with syber gold DNA safe stain dye, then visualized using a UV transilluminator. DNA molecular weight marker (Fermentas, 100 bp Ladder) was used to assess the size of the PCR products.

\subsection{Statistical Analysis}

Quantitative data were expressed as a mean \pm standard deviation (SD). Differences Categorical variables were presented using frequency counts and compared with a logistic regression test. Deviation from Hardy-Weinberg equilibrium was analyzed by a $\chi^{2}$ test. Odds ratio (OR) and 95\% confidence interval (CI) were calculated as an estimate of risk. $\mathrm{P}<0.05$ was considered statistically significant. All statistical analyses were performed with SPSS 16.0 software.

\section{Results}

The schematic representations of ARMS-PCR for each polymorphic marker were shown in Figures 1 - 3. The total 73 individuals with uterine myoma tumors and 73 individuals as the control subjects were involved in this study.

The allelic and genotype frequencies of two polymorphic markers of MTHFR rs1801131, rs1801133 were presented in Tables 2 and 3 respectively.

After analyzing MTHFR C677T mutation and determining of allele frequency in normal and uterine myoma cases, there was no statically significant difference between this mutation and risk of myoma was found $(P>0.05)$. The frequency of the TT genotype in patients and controls was $6.8 \%$ and $5.5 \%$ respectively. The relationship between the $\mathrm{T}$ allele carriers and myoma was also analyzed which resulted in no relationship. By genotyping of MTHFR A1298C, we found a significant association between heterozygote genotype and the risk of uterine myoma $(\mathrm{P}=0.04)$. Also 
Figure 1. The Product of ARMS-PCR of the Polymorphism C677T (rs1801133) of MTHFR Gene on 2\% Agarose Gel Electrophoresis

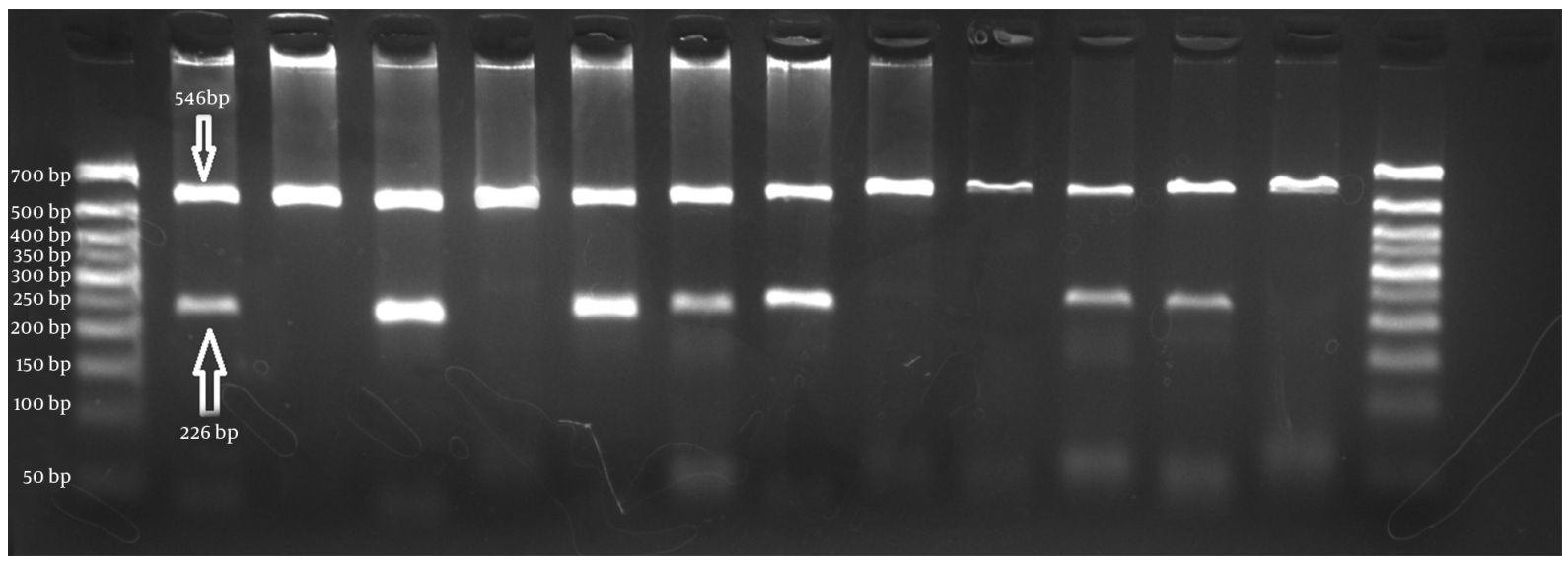

First well in each case belongs to the primer for wild type allele $\mathrm{C}$ and the second well for mutant primer T (left to right). Wells 2/3, 4/5, 8/9 and 12/13 show homozygote CC genotype. Wells $6 / 7$ is an indicator of heterozygous CT. Wells 10/11 are for the homozygote genotype TT. The 50bp size marker is loaded in first and last wells.

Figure 2. A Representation of the Products of ARMS-PCR of A1298C (rs1801131) of MTHFR Gene on 2\% Agarose Gel Electrophoresis

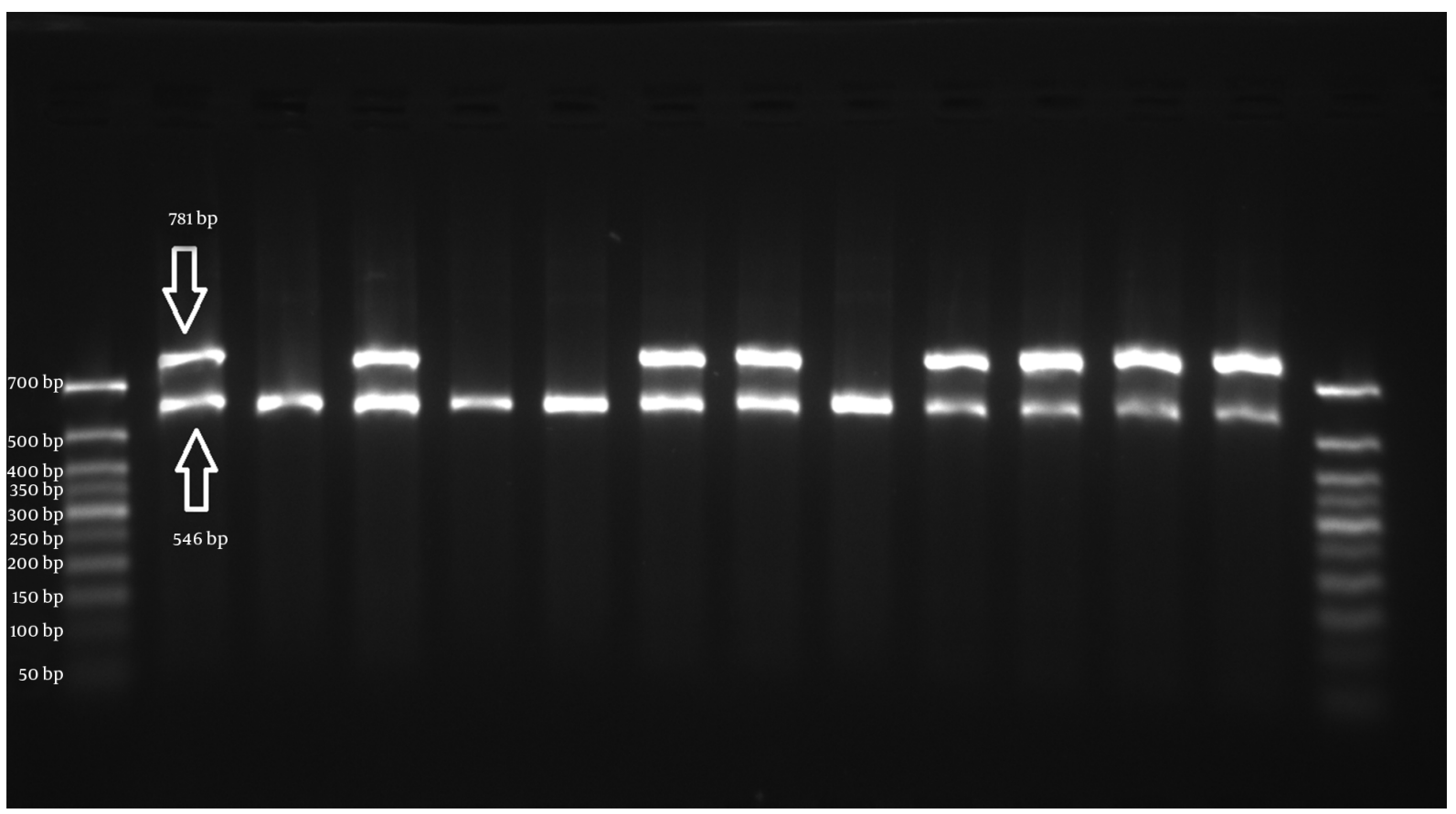

First well is for wild type allele A and the latter for mutant allele C (left to right). Wells 2/3, 4/5 and 8/9 show AA genotype. Wells $10 / 11$ \& 12/13 is for AC genotype and 6/7 belong to homozygote CC genotype. The 5obp size marker is loaded in first and last wells. 
Table 1. The Sequence and other Characteristics of the Primer Pairs Used in the Amplification Process

\begin{tabular}{|c|c|c|c|}
\hline & Marker & Sequence $5^{\prime}$ to $3^{\prime}$ & PCR Product, bp \\
\hline \multirow{3}{*}{1} & \multirow{3}{*}{ MTHFR (1298) } & $\begin{array}{c}\text { Forward normal: } \\
\text { TTGAAGGAGAAGGTGTCTGCGGTAGC }\end{array}$ & \multirow{3}{*}{781} \\
\hline & & $\begin{array}{c}\text { Forward mutant: } \\
\text { TTGAAGGAGAAGGTGTCTGCGGTAGT }\end{array}$ & \\
\hline & & $\begin{array}{c}\text { Reverse common: } \\
\text { CAAGTGATGCCCATGTCGGTG }\end{array}$ & \\
\hline \multirow{3}{*}{2} & \multirow{3}{*}{ MTHFR (677) } & $\begin{array}{c}\text { Forward normal: } \\
\text { AAGCTGCGTGATGATGAACTC }\end{array}$ & \multirow{3}{*}{226} \\
\hline & & $\begin{array}{c}\text { Forward mutant: } \\
\text { AAGCTGCGTGATGATGAACTT }\end{array}$ & \\
\hline & & $\begin{array}{c}\text { Reverse common: } \\
\text { TTGGAAGGTGCAAGATCAGAG }\end{array}$ & \\
\hline \multirow{3}{*}{3} & \multirow{3}{*}{ EPCR } & $\begin{array}{c}\text { Forward normal: } \\
\text { CACACCAGCAATGATGATACT }\end{array}$ & \multirow{3}{*}{243} \\
\hline & & $\begin{array}{c}\text { Forward mutant: } \\
\text { CACACCAGCAATGATGATACG }\end{array}$ & \\
\hline & & $\begin{array}{c}\text { Reverse common: } \\
\text { TAGAGCAACAAGAGGCCCACAG }\end{array}$ & \\
\hline \multirow{2}{*}{4} & \multirow{2}{*}{ HBG1 } & F: AACGGCTGACAAAAGAAGTCCTGG & \multirow{2}{*}{564} \\
\hline & & R: TGCCAGGCACAGGGTCCTTCC & \\
\hline
\end{tabular}

Abbreviations: MTHFR, methylene-tetrahydrofolate reductase; EPCR, endothelial protein C receptor; HBG1, hemoglobin subunit gamma 1.

Figure 3. The Product of ARMS-PCR of the Polymorphism rs867186 of EPCR Gene on 2\% Agarose Gel Electrophoresis

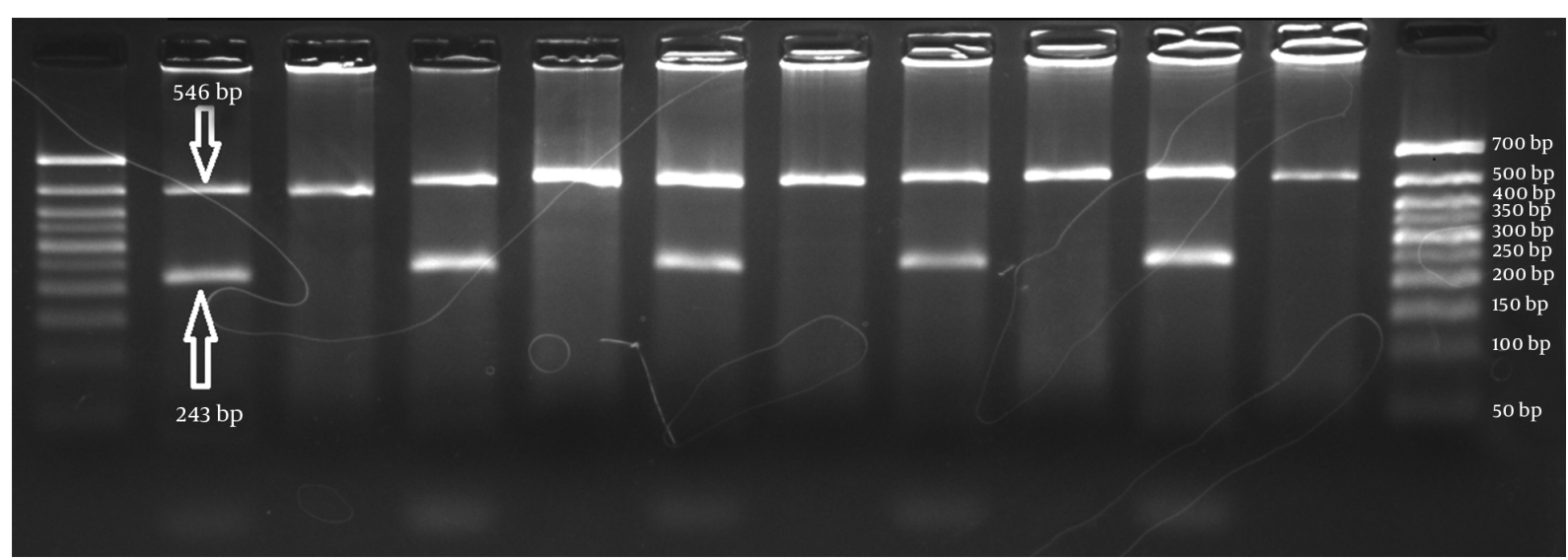

From the two wells for each sample, the first is for allele A and second for allele G (left to right). Since in all samples, amplification occurs only in first well, the genotype AA has confirmed for all. The 5obp size marker is loaded in first and last wells.

genotypes with at least one $\mathrm{C}$ allele (CC + CA vs. AA) showed a remarkable increase in risk of myoma (OR: 5.6, 95\% CI: 1.18-26.6, $\mathrm{P}=0.01)$. The $\mathrm{C}$ allele frequency was 0.02 in myoma patients compared with 0.08 in controls (OR: 6.44, 95\%CI: 0.4-29.3, $\mathrm{P}=0.01)$. In this study minor allele for rs86786 in the EPCR gene was absent in both patient and control groups. The genotype frequencies in both patients $(\mathrm{df}=1, \mathrm{P}>0.05)$ and controls $(\mathrm{df}=1, \mathrm{P}>0.05)$ in the stud- ied SNPs were not significantly differ from those expected for populations in Hardy-Weinberg equilibrium.

\section{Discussion}

A statistically significant difference was observed between patients and the control group regarding the frequency of alleles $C$ in the MTHFR $(A 1298 C)$ gene $(P=0.01)$. 
Table 2. Distribution of A1298C MTHFR Mutation in Case and Control Groups

\begin{tabular}{|c|c|c|c|c|c|}
\hline A1298C Polymorphism & Controls (120), No. (\%) & Patients (120), No. (\%) & P Value & OR & 95\% CI \\
\hline \multicolumn{6}{|l|}{ Genotypes } \\
\hline AA & $71(97.3)$ & $63(86.3)$ & - & 1 & reference \\
\hline AC & $0(0.0)$ & $8(11)$ & 0.04 & 0.22 & $0.04-1.08$ \\
\hline $\mathrm{CC}$ & $2(2.7)$ & $2(2.7)$ & 0.99 & 0.0 & 0.0 \\
\hline $\mathrm{CC}+\mathrm{AC}$ & $2(2.7)$ & $10(13.7)$ & 0.01 & 5.6 & $1.18-26.6$ \\
\hline \multicolumn{6}{|l|}{ Alleles } \\
\hline A & $134(0.92)$ & $144(0.98)$ & - & 1 & reference \\
\hline C & $12(0.08)$ & $2(0.02)$ & 0.01 & 6.44 & $0.4-29.3$ \\
\hline
\end{tabular}

Abbreviations: OR, odds ratio; 95\%CI, confidence interval.

Table 3. Distribution of C677T MTHFR Mutation in Case and Control Groups

\begin{tabular}{|c|c|c|c|c|c|}
\hline C677T Polymorphism & Controls (120), No. (\%) & Patients (120), No. (\%) & PValue & OR & 95\% CI \\
\hline \multicolumn{6}{|l|}{ Genotype } \\
\hline $\mathrm{CC}$ & $62(84.9)$ & $59(80.8)$ & - & 1 & reference \\
\hline CT & $7(9.6)$ & $9(12.3)$ & 0.57 & 0.74 & $0.26-2.11$ \\
\hline TT & $4(5.5)$ & $5(6.8)$ & 0.69 & 0.76 & $0.19-2.97$ \\
\hline $\mathrm{TT}+\mathrm{CT}$ & $11(15.1)$ & $10(13.7)$ & 0.51 & 0.75 & $0.31-1.77$ \\
\hline \multicolumn{6}{|l|}{ Allele } \\
\hline $\mathrm{C}$ & $131(0.9)$ & $127(0.87)$ & - & 1 & reference \\
\hline $\mathrm{T}$ & $15(0.1)$ & $19(0.13)$ & 0.46 & 0.76 & $0.37-1.57$ \\
\hline
\end{tabular}

Abbreviations: OR, odds ratio; 95\%CI, confidence interval.

Uterine myomas is the most prevalent tumor in women's reproductive or even after menopause age [1]. Since tumorigenesis and thrombosis closely connected, involved factors in thrombosis could be considered as genetic markers for myoma tumor, and therapeutic targets.

In this study, we focused on the most effective variations in two thrombotic factors, EPCR (rs867186) and MTHFR(rs1801113, rs1801133), and their effects on myoma tumor incident for the first time. The association of MTHFR genetic variations; rs1801133, rs1801131; with several types of tumors such as gastric cancer, breast cancer, colorectal cancer, ovarian cancer and prostate cancer have been reported $[13,14,19,20]$, and correlation of rs867186 in EPCR gene with venous thromboembolism and homeostasis was previously demonstrated $[21,22]$.

The presence of the G allele makes EPCR more sensitive to cleavage and shades EPCR from endothelial cells [23]. The protein $\mathrm{C}$ anticoagulant pathway plays as a major regulator of thrombosis, the inflammatory response and endothelial cell apoptosis $[24,25]$. The endothelial PC recep- tor (EPCR) which mainly expressed on the endothelial cells of large vessels is mediator for these processes [26]. The rs867186 polymorphism in the EPCR gene in the membrane spanning domain of EPCR resulting in variation in EPCR levels in serum between $56 \%$ and $87 \%$ [22, 27, 28]. The variation in the EPCR gene or plasma sEPCR levels affect the risk of thrombosis [27, 28].

MTHFR mutations could increase the risk of tumorigenesis in two ways: firstly, lower levels of MTHFR activity could be the cause of a decrease in the level of 5-MTHFR an increase in homocysteine level, which lead to venous thrombosis. Since S-adenosyl-homocysteine [28], a product of MTHFR gene, acts as an inhibitor of several methyl transferases: also the reduction of 5-MTHFR may lead to disruption of DNA methylation and changing in expression of genes and altering cell proliferation [17, 29].

Our results demonstrated no association between myoma tumor and C677T variant in our populations, although the frequency of the $\mathrm{T}$ allele was higher in myoma group. The presence of the C allele of A1298C associated 
with the increased risk of myoma. Our results showed that the presence of at least one $C$ allele increases the chance of uterine myoma.

Although, based on our knowledge, there is no similar study on myoma, several controversial researches have been done on the role of these two variations of MTHFR gene and different type of tumor: Jakubowska study showed that MTHFR C677T was associated with an increased risk and 1298//C polymorphism has a negative effect on incidence of breast and ovarian tumor [30]. Sharp found both polymorphisms in association with breast cancer [31]. Other studies on breast cancer [32], colorectal cancer [28], gastric cancer [33] and lung cancer [34] also did not find any correlation between the existence of the $\mathrm{T}$ allele of C677T polymorphism and increasing risk of tumorigenesis.

Our results did not show any association between rs867186 in EPCR gene and the risk of myoma incidence. Genotyping showed the minor allele of rs867186 variation was absent in our participants. However, there have been no published study in this area yet, but other studies on other tumors have been done and have shown EPCR stimulates cell migration in breast cancer and stop the metastasis of tumor cells in lung cancer [4].

In conclusion, we reported the first prospective study, investigating the association between three coagulation related variations and risk of myoma. This study revealed a significant association between A1298T variation and myoma incidence that could be considered for further investigations and its potential for diagnosis of having a chance of myoma. Although same results did not gain for two other variations, the more research elucidate the role of MTHFR variations in tumorigenesis and future studies in larger populations is proposed to reveal the actual role of MTHFR variations in myoma.

\section{Acknowledgments}

The data reported in this paper were extracted from the thesis entitled "Association assessment between MTHFR C677T (rs1801133), A1298C (rs1801131) and EPCR (rs867186) common polymorphisms and uterine myoma in women" by Razieh Moghtaderi. Thesis code is: 16030517922004 .

\section{Footnotes}

Authors' Contribution: Ahmad Ebrahimi: study concept and design and administrative support; Razieh Moghtaderi: technical and material support and preparing first draft of the manuscript; Mahboobeh Nasiri: interpretation of data, critical revision of the manuscript for important intellectual content, statistical analysis and study supervision.

Funding/Support: This study was supported by Islamic Azad University, Arsanjan branch.

\section{References}

1. Duhan N. Current and emerging treatments for uterine myoma - an update. Int J Womens Health. 2011;3:231-41. doi: 10.2147/IJWH.S15710. [PubMed: 21892334].

2. Terry KL, Tworoger SS, Goode EL, Gates MA, Titus-Ernstoff L, Kelemen LE, et al. MTHFR polymorphisms in relation to ovarian cancer risk. Gynecol Oncol. 2010;119(2):319-24. doi: 10.1016/j.ygyno.2010.08.007. [PubMed: 20817226].

3. Parker WH. Etiology, symptomatology, and diagnosis of uterine myomas. Fertil Steril. 2007;87(4):725-36. doi: 10.1016/j.fertnstert.2007.01.093. [PubMed: 17430732].

4. Ruf W, Schaffner F. Role of the protein $C$ receptor in cancer progression. Thromb Res. 2014;133 Suppl 2:85-9. doi: 10.1016/S00493848(14)50014-X. [PubMed: 24862151].

5. Rickles FR, Falanga A. Activation of clotting factors in cancer. Cancer Treat Res. 2009;148:31-41. doi: 10.1007/978-0-387-79962-9_3. [PubMed: 19377917].

6. Klerk CP, Smorenburg SM, Otten HM, Lensing AW, Prins MH, Piovella $\mathrm{F}$, et al. The effect of low molecular weight heparin on survival in patients with advanced malignancy.JClin Oncol. 2005;23(10):2130-5. doi: 10.1200/JCO.2005.03.134. [PubMed: 15699479].

7. Altinbas M, Coskun HS, Er O, Ozkan M, Eser B, Unal A, et al. A randomized clinical trial of combination chemotherapy with and without low-molecular-weight heparin in small cell lung cancer. $J$ Thromb Haemost. 2004;2(8):1266-71. doi: 10.1111/j.1538-7836.2004.00871.x. [PubMed: 15304029].

8. Singh A, Pandey S, Pandey LK, Saxena AK. In human alleles specific variation of MTHFR C677T and A1298C associated "risk factor" for the development of ovarian cancer. J Exp Ther Oncol. 2015;11(1):67-70. [PubMed: 26259392].

9. Miri-Moghaddam E, Saravani S, Garme Y, Khosravi A, Bazi A, Motazedian J. Methylenetetrahydrofolate reductase C677T and A1298C gene polymorphisms in oral squamous cell carcinoma in south-east Iran. J Oral Pathol Med. 2016;45(2):96-100. doi: 10.1111/jop.12343. [PubMed: 26218632].

10. Ghasemi S, Tavakoli A, Moghadam M, Zargar MA, Abbaspour M, Hatamnejadian N, et al. Risk of prostate cancer and thrombosisrelated factor polymorphisms. Biomed Rep. 2014;2(1):53-6. doi: 10.3892/br.2013.180. [PubMed: 24649068].

11. Dennis J, Johnson CY, Adediran AS, de Andrade M, Heit JA, Morange PE, et al. The endothelial protein C receptor (PROCR) Ser219Gly variant and risk of common thrombotic disorders: a HuGE review and meta-analysis of evidence from observational studies. Blood. 2012;119(10):2392-400. doi: 10.1182/blood-2011-10-383448. [PubMed: 22251481].

12. Nishikawa H, Ideishi M, Nishimura T, Kawamura A, Kamochi H Tahara H, et al. Deep venous thrombosis and pulmonary thromboembolism associated with a huge uterine myoma-a case report. Angiology. 2000;51(2):161-6. [PubMed: 10701725].

13. Wu HC, Chang CH, Tsai RY, Lin CH, Wang RF, Tsai CW, et al. Significant association of methylenetetrahydrofolate reductase single nucleotide polymorphisms with prostate cancer susceptibility in taiwan. Anticancer Res. 2010;30(9):3573-7. [PubMed: 20944139].

14. Ericson U, Sonestedt E, Ivarsson MI, Gullberg B, Carlson J, Olsson H, et al. Folate intake, methylenetetrahydrofolate reductase polymorphisms, and breast cancer risk in women from the Malmo Diet and 
Cancer cohort. Cancer Epidemiol Biomarkers Prev. 2009;18(4):1101-10. doi:10.1158/1055-9965.EPI-08-0401. [PubMed:19336565].

15. Afzal S, Jensen SA, Vainer B, Vogel U, Matsen JP, Sorensen JB, et al. MTHFR polymorphisms and 5-FU-based adjuvant chemotherapy in colorectal cancer. Ann Oncol. 2009;20(10):1660-6. doi: 10.1093/annonc/mdp046. [PubMed: 19465420].

16. Kang SS, Wong PW, Malinow MR. Hyperhomocyst(e)inemia as a risk factor for occlusive vascular disease. Annu Rev Nutr. 1992;12:279-98. doi:10.1146/annurev.nu.12.070192.001431. [PubMed: 1503807].

17. Varga EA, Sturm AC, Misita CP, Moll S. Cardiology patient pages. Homocysteine and MTHFR mutations: relation to thrombosis and coronary artery disease. Circulation. 2005;111(19):289-93. doi: 10.1161/01.CIR.0000165142.37711.E7. [PubMed: 15897349].

18. Haynes MC, Lu BY, Winkel AF. Ovarian vein thrombophlebitis related to large uterine myoma. Obstet Gynecol. 2014;123(2 Pt 2 Suppl 2):450-3. doi: 10.1097/AOG.0000000000000091. [PubMed: 24413242].

19. Roberts-Thomson IC, Butler WJ. Polymorphism and gastric cancer. J Gastroenterol Hepatol. 2005;20(5):793-4. doi: 10.1111/j.14401746.2005.03938.x. [PubMed:15854000].

20. Levine AJ, Figueiredo JC, Lee W, Poynter JN, Conti D, Duggan DJ, et al. Genetic variability in the MTHFR gene and colorectal cancer risk using the colorectal cancer family registry. Cancer Epidemiol Biomarkers Prev. 2010;19(1):89-100. doi: 10.1158/1055-9965.EPI-09-0727. [PubMed: 20056627].

21. Mari D, Ogliari G, Castaldi D, Vitale G, Bollini EM, Lio D. Hemostasis and ageing. Immun Ageing. 2008;5:12. doi: 10.1186/1742-4933-5-12. [PubMed: 18947391].

22. Uitte de Willige S, Van Marion V, Rosendaal FR, Vos HL, de Visser MC, Bertina RM. Haplotypes of the EPCR gene, plasma sEPCR levels and the risk of deep venous thrombosis. J Thromb Haemost. 2004;2(8):1305-10. doi:10.1046/j.1538-7836.2004.00855.x. [PubMed:15304035].

23. Qu D, Wang Y, Song Y, Esmon NL, Esmon CT. The Ser219->Gly dimorphism of the endothelial protein $C$ receptor contributes to the higher soluble protein levels observed in individuals with the $\mathrm{A} 3$ haplotype. J Thromb Haemost. 2006;4(1):229-35. doi: 10.1111/j.15387836.2005.01676.x. [PubMed: 16409473].

24. Castellino FJ, Ploplis VA. The protein C pathway and pathologic processes. J Thromb Haemost. 2009;7 Suppl 1:140-5. doi: 10.1111/j.15387836.2009.03410.x. [PubMed: 19630787].

25. Menschikowski M, Hagelgans A, Eisenhofer G, Siegert G. Regulation of endothelial protein $\mathrm{C}$ receptor shedding by cytokines is mediated through differential activation of MAP kinase signaling pathways. Exp Cell Res. 2009;315(15):2673-82. doi: 10.1016/j.yexcr.2009.05.015. [PubMed: 19467228].

26. Anastasiou G, Politou M, Rallidis L, Grouzi E, Karakitsos P, Merkouri E, et al. Endothelial Protein C Receptor Gene Variants and Risk of Thrombosis. Clin Appl Thromb Hemost. 2016;22(2):199-204. doi: 10.1177/1076029614547261. [PubMed: 25760048].

27. Bertina RM. Factor V Leiden and other coagulation factor mutations affecting thrombotic risk. Clin Chem. 1997;43(9):1678-83. [PubMed: 9299960].

28. Slattery ML, Potter JD, Samowitz W, Schaffer D, Leppert M. Methylenetetrahydrofolate reductase, diet, and risk of colon cancer. Cancer Epidemiol Biomarkers Prev. 1999;8(6):513-8. [PubMed:10385141].

29. Crott JW, Mashiyama ST, Ames BN, Fenech MF. Methylenetetrahydrofolate reductase C677T polymorphism does not alter folic acid deficiency-induced uracil incorporation into primary human lymphocyte DNA in vitro. Carcinogenesis. 2001;22(7):1019-25. [PubMed: 11408344].

30. Jakubowska A, Gronwald J, Menkiszak J, Gorski B, Huzarski T, Byrski $\mathrm{T}$, et al. Methylenetetrahydrofolate reductase polymorphisms modify BRCA1-associated breast and ovarian cancer risks. Breast Cancer Res Treat. 2007;104(3):299-308. doi: 10.1007/s10549-006-9417-3. [PubMed: 17063264].

31. Sharp L, Little J, Schofield AC, Pavlidou E, Cotton SC, Miedzybrodzka Z. Folate and breast cancer: The role of polymorphisms in methylenetetra hydrofolate reductase (MTHFR). Cancer Lett. 2002;18(1):65-71. doi: 10.1016/S0304-3835(02)00030-7.

32. Rai PS, Pai GC, Alvares JF, Bellampalli R, Gopinath PM, Satyamoorthy $\mathrm{K}$. Intraindividual somatic variations in MTHFR gene polymorphisms in relation to colon cancer. Pharmacogenomics. 2014;15(3):349-59. doi: 10.2217/pgs.14.4. [PubMed: 24533714].

33. Shen H, Xu Y, Zheng Y, Qian Y, Yu R, Qin Y, et al. Polymorphisms of 5,10methylenetetrahydrofolate reductase and risk of gastric cancer in a Chinese population: a case-control study. Int J Cancer. 2001;95(5):3326. [PubMed: 11494235].

34. Shen H, Spitz MR, Wang LE, Hong WK, Wei Q. Polymorphisms of methylene-tetrahydrofolate reductase and risk of lung cancer: a casecontrol study. Cancer Epidemiol Biomarkers Prev. 2001;10(4):397-401. [PubMed: 11319182]. 